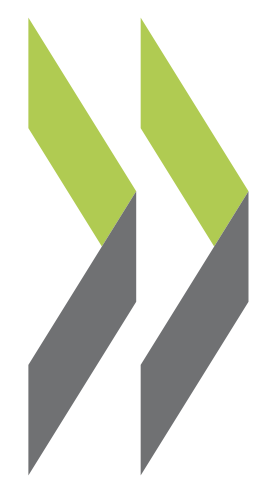

OECD Economics Department Working Papers No. 236

Predicting The Evolution and Effects of The Asia Crisis from The OECD Perspective

Pete Richardson, Ignazio Visco, Claude Giorno 


\section{Unclassified}

OECD OII OCDE

Organisation de Coopération et de Développement Economiques

Organisation for Economic Co-operation and Development

ECONOMICS DEPARTMENT

ECO/WKP(2000)9

OLIS : 06-Apr-2000

Dist. : 14-Apr-2000

PREDICTING THE EVOLUTION AND EFFECTS OF THE ASIA CRISIS

FROM THE OECD PERSPECTIVE

ECONOMICS DEPARTMENT WORKING PAPERS NO. 236

by

Pete Richardson, Ignazio Visco and Claude Giorno

Most Economics Department Working Papers beginning with No. 144 are now available through OECD's Internet Web site at http://www.oecd.org/eco/eco.

89741

Document complet disponible sur OLIS dans son format d'origine

Complete document available on OLIS in its original format 


\section{ABSTRACT/RÉSUMÉ}

Over the past two years, the key trading economies in SE Asia experienced major economic crises, involving financial turbulence, large capital outflows and currency depreciations. These, in turn, resulted in severe financial constraints and business failures and required major domestic adjustments and massive swings in their currentaccount balance of payments positions. The associated economic recessions had major effects on the economies in question and, because of constraints on their capacity to invest and import, a significant impact on the rest of the world, so that world trade and output growth slowed significantly and world commodity markets weakened substantially over the period.

This paper looks at the wider macroeconomic consequences of the Asia crisis and their predictability from the perspective of the OECD countries. In doing so it examines some of the major aspects of the Asia crisis, its effects on the world situation and their predictability, assisted by the OECD's world econometric model INTERLINK. A broad conclusion is the OECD significantly under-estimated the scale of the crisis at the time and this was reflected in its assessments of the wider consequences for the world economy. However, model-based assessments would have been largely correct had better information been available on the size, composition and distribution of the shock. The analysis also provides evidence on the impact of other influences over the period, in particular the strength of stock markets and the relative strengths and weaknesses of the US and Japanese economies, and suggests that these events were also closely linked to the Asia crisis and to some extent reflect important financial transmission mechanisms which are mostly absent from econometric models and model based analyses.

JEL Code: F17, F42,F47

Keyword: Asia Crisis

$* * * * *$

Au cours des deux dernières années, les économies d'Asie du sud-est les plus importantes du point de vue des échanges commerciaux ont connu des crises économiques majeures qui se sont traduites par de fortes perturbation de leurs marchés financiers, des sorties de capitaux importantes et des dépréciations de taux de change. Celles-ci ont entraîné de sévères contraintes financières et des faillites d'entreprises et nécessité des ajustements substantiels de demande intérieure et des modifications massives des positions des balances des paiements courants dans ces pays. Les récessions économiques qui ont suivi ont eu des effets très importants sur les économies en question et, du fait des contraintes qui ont affecté leur capacité d'investir et d'importer, ont eu un impact significatif sur le reste du monde. Ainsi, le commerce et la production mondiale ont ralenti significativement tandis que les marchés internationaux des produits de base se sont affaiblis substantiellement au cours de la période.

Ce papier examine sur un plan plus large les conséquences macro-économiques de la crise asiatique et leur prévisibilité du point de vue des pays de l'OCDE. Pour ce faire, il analyse certains des principaux aspects de la crise asiatique, ses effets sur la situation mondiale et leur prévisibilité à l'aide du modèle économétrique international INTERLINK de l'OCDE. Une conclusion générale est que l'OCDE a initialement sous-estimé de façon significative l'ampleur de cette crise et ceci s'est reflété dans son évaluation de ses conséquences économiques globales au niveau mondial. Cependant, des évaluations estimées à l'aide d'un modèle aurait été globalement correctes si de meilleures informations avaient été disponibles concernant l'ampleur, la composition et la distribution de ce choc. L'analyse fournit aussi des indications sur l'impact d'autres facteurs qui ont joué un rôle au cours de cette période, en particulier la force des marchés boursiers et la vigueur et faiblesse respectives des économies américaine et japonaise. Elle permet d'indiquer que ces événements étaient aussi étroitement liés à la crise asiatique et, dans une certaine mesure, reflète d'important mécanismes de transmission qui sont pour la plupart absents des modèles économétriques et des analyses effectuées à l'aide de ces outils.

Copyright: OECD, 2000

Applications for permission to reproduce or translate all, or part of, this material should be made to: Head of Publications Service, OECD, 2 rue André-Pascal, 75775 PARIS CEDEX 16, France 
ECO/WKP(2000)9

TABLE OF CONTENTS

PREDICTING THE EVOLUTION AND EFFECTS OF THE ASIA CRISIS FROM

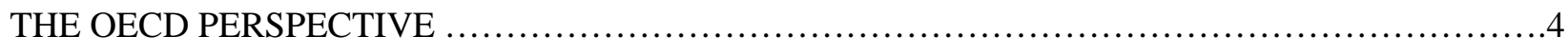

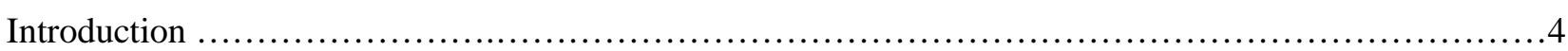

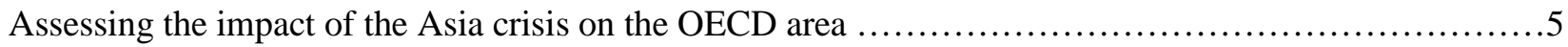

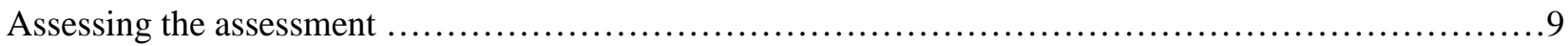

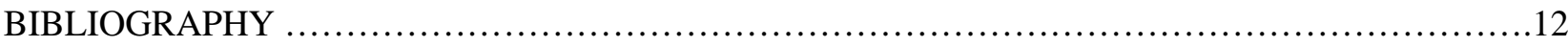

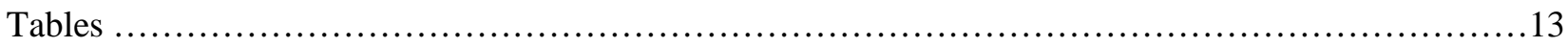

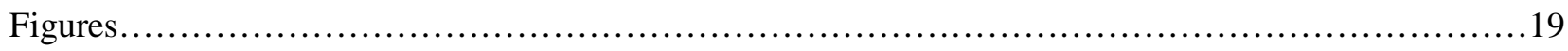


ECO/WKP(2000)9

\title{
PREDICTING THE EVOLUTION AND EFFECTS OF THE ASIA CRISIS FROM THE OECD PERSPECTIVE
}

\author{
by Pete Richardson, Ignazio Visco and Claude Giorno ${ }^{1}$
}

\section{Introduction}

1. Over the past two years the key economies in SE Asia, ones more commonly known for their competitive and dynamic trade and growth performances in previous decades, have experienced major economic crises. ${ }^{2}$ These have involved a combination of major financial turbulence, substantial capital outflows and currency depreciations. As a result the economies in question experienced severe constraints on financial flows and investments and widespread business bankruptcies, requiring major domestic adjustments and massive swings in current-account positions. The associated economic recessions have had major effects on the domestic growth and economic performance of the Asia-5 economies and, in particular, imposed significant constraints on their capacity to invest and import from the rest of the world. As a result, world trade and output growth slowed significantly through 1997 and 1998 and competitiveness positions shifted, with important consequences for the export and growth prospects of Asia's trading partners. At the same time, world commodity markets weakened substantially and financial conditions in other parts of the world had to adjust, in part to accommodate the effects of the crisis.

2. This paper looks at the macroeconomic consequences of these events and their predictability from the particular perspective of the OECD. Whilst the OECD Secretariat routinely monitors economic events in the non-OECD countries and regions as part of regular world economic assessment and forecasting exercises, it does so drawing in part on information based on the more specialised expertise of the other international organisations, such as the IMF and the World Bank, with respect to economies in those regions. Much of the OECD's focus of interest in the Asia crisis, particularly in its early stages, was therefore on the wider implications for the world economy and likely developments in member countries. Thus the main events going on within the Asia-5 economies were taken as a largely exogenous input to the OECD's international assessments over the period. ${ }^{3}$

3. The present analysis therefore examines the predictability and forecasting errors associated with the Asia crisis largely from the point of view of its implications for economic developments in the rest of the world and, in particular, OECD member countries. It does so in the context of the various published

1. This paper was originally prepared as a contribution to the World Bank Conference "The East Asian Crisis: Lessons for Today and for Tomorrow", May 1999, and is published in Economic Notes, Volume 28, No.3, November 1999. The authors would like to thank numerous colleagues who contributed to this study and the body of work it draws on and provided comments on earlier drafts, in particular Martine Durand, Michael Feiner and Dave Turner. Special thanks also go to Marie-Christine Bonnefous and Laurence Le Fouler for technical and statistical support; and to Rosemary Chahed and Jan-Cathryn Davies for technical preparation. The views expressed are those of the authors and do not necessarily represent those of the OECD or its member countries.

2. These countries include, in particular, Korea and four non-OECD Asian countries - Indonesia, Malaysia, the Philippines and Thailand - hereafter referred to as the "Asia-5".

3. Korea is an important exception, being a full member of the OECD and therefore being included as an integral part of the member country assessments. 
assessments and model-based analyses of the wider international economic effects as presented in recent editions of the OECD Economic Outlook.

4. An important caveat to the exercise is that whereas econometric models play an important role in the OECD's assessments and projection exercises, particularly in ensuring the international consistency and in simulating the effects of external events or policy shocks, the OECD's short-term projections also contain an important judgmental element and are not exclusively model based. ${ }^{4}$ This means that the relevant prediction errors are not specifically captured by individual equation residuals of the OECD's international model, INTERLINK, but rather need to be inferred more carefully from relevant simulation analyses. ${ }^{5}$ In any event, the Asia crisis was one of a number of unanticipated influences on the world economy during the period and it is, therefore, extremely difficult to isolate in terms of predictive accuracy even within a full model-based forecasting framework.

5. The rest of this paper is organised broadly as follows. The following section first reviews some of the salient features of the Asia crisis from an OECD perspective and the way in which these influenced the OECD's assessments of trade and growth prospects for the OECD economies over the period. It goes on to examine the successive assessments of the external shocks involved and the corresponding simulation analyses of their effects on main OECD countries and regions.

6. A further section then examines the issue of how useful models were in making the appropriate projections for the OECD area, taking account of the effects of the crisis, conditional on the information available at given points in time. This analysis also provides a basis for identifying the effects of a number of other key elements affecting the OECD projections and thereby some relevant overall measures of forecasting accuracy.

7. A broad conclusion is that, like many other international commentators, the OECD assessments significantly under-estimated the scale of the crisis within Asia, particularly in its early stages and, therefore, its direct effects on OECD countries. However, model-based assessments of the situation were, qualitatively speaking, useful and would have been largely correct for the OECD area as a whole had better information been available on the size, composition and distribution of the Asia shock. The analysis also provides evidence on the importance of other shocks on the OECD economy and their contribution to overall forecasting errors. Notable amongst these are the continuing strength of stock markets, and the respective strength and weakness of the United States and Japanese domestic economies during 1998, both of which reflect, to a greater or lesser extent, influences which were also linked to the Asia crisis.

\section{Assessing the impact of the Asia crisis on the OECD area}

8. Although financial linkages played an important role in the underlying causes and transmission of the crisis, the main influence of the developments in Asia on the OECD countries and other world regions were seen as being largely through international trade linkages. The size of these depended critically on how developments in Asia evolved, particularly as regards exchange rates and the speed with which domestic demand in the crisis countries fell. Particularly beyond the short term, a high degree of uncertainty attached to both the size of the trade adjustments required in Japan and countries outside Asia and the time frame in which they were likely to occur.

4. A detailed account of the background, scope and processes of the OECD's economic projections is given by OECD (1999a).

5. For general background to the OECD INTERLINK model, see Richardson et al. (1999), Richardson (1988) and Turner, et al. (1996). 
9. The direct trade-related effects on countries outside the Asia-5 were expected to operate through four main channels:

- a collapse in domestic demand in crisis countries, and general weakness elsewhere in the region, being reflected in sharp reductions in import demands of the region and slower export market growth for countries outside it;

- exchange rate depreciations in most economies in emerging Asia, affecting price and cost competitiveness vis-à-vis other economies, not only in those countries but also in home and third markets;

- depressed activity, possibly encouraging businesses in emerging Asia to give higher priority to exporting than cost and price considerations alone might justify; ${ }^{6}$ and

- weak oil and commodity prices, reducing incomes of important oil or commodity exporting countries, but also improving the terms of trade faced by the major OECD countries.

10. An overview of trade and balance-of-payments developments through the period reveals the following broad picture. Between 1996 and 1998 the combined current-account balance of the crisis economies increased by more than $\$ 125$ billion, going from a combined deficit of $\$ 60$ billion to a combined surplus of $\$ 65$ billion. ${ }^{7}$ With the surplus in Japan increasing by about $\$ 55$ billion over the same period and that in the European Union remaining broadly stable, the main offsetting change was a further widening of the current-account deficit in the United States by about $\$ 100$ billion (Figure 1). Offsets can also be found among major oil-producing countries (reflecting weakening oil prices) as well as other members of NAFTA and countries in Latin America. These overall movements, however, reflect a wider range of influences than those purely associated with the Asia crisis, in particular the respective movements in underlying growth rates and in saving and investment balances of the main OECD economies. $^{8}$

11. Looking more narrowly at trade balances, that of the Asia-5 increased by about $\$ 120$ billion between 1996 and 1998. Over $\$ 80$ billion of this increase can be accounted for by a deterioration in the bilateral trade balances of OECD countries, and about $\$ 70$ billion by those of the three main OECD regions, spread more or less evenly across them in absolute terms (Table 1, top panel). ${ }^{9}$ Up until now, the adjustment to trade balances from the Asia-5 has come about almost entirely from a massive reduction in the dollar value of imports, mostly occurring in 1998 (Figure 2). Indeed, provisional estimates suggest that the decline in Asia-5 import volumes directly accounted for a fall in world trade growth of about 11/2 percentage points in 1998 compared with 1997.

12. Although evidence is patchy, available official data and other estimates suggest that there has been strong growth in export volumes from the Asia-5, despite supply constraints arising from difficulties

6. However, it was also recognised that exporters in crisis countries might have difficulties exploiting improved competitiveness insofar as credit problems prevented them from obtaining necessary inputs.

7. Such changes were massive in relation to GDP in the zone, for example in the case of Korea the swing in the current balance over this period amounted to about 17 per cent of GDP.

8. A more detailed analysis of the relative contributions of these factors over the recent past is given by "Causes of the recent widening of OECD current-account imbalances", in OECD (1999b).

9. Outside the three main OECD regions, Australia and New Zealand are the OECD countries with which the bilateral trade balance with Asia-5 has most severely worsened. Between 1996 and 1998, the combined trade balance of Australia and New Zealand worsened by $\$ 7$ billion, equivalent to about 11/2 per cent of their combined GDPs. 
in obtaining export credits or imported inputs for certain export categories. ${ }^{10}$ However there were also substantial reductions in dollar export prices as exchange rates fell, with little overall positive effect on Asia-5 export values in dollar terms.

13. Reflecting import contraction in Asia-5, there were correspondingly large falls in the value of OECD exports to the region between 1996 and 1998. Over the period, the dollar value of exports from Japan and the European Union fell by about 45 per cent and from the United States by about 25 per cent (Table 1, middle panel). However, for Japan this represents a reduction in total exports of nearly 8 per cent, reflecting the relative importance of the Asia-5 as an export market, compared with $2 \frac{1}{2}$ to 3 per cent for the United States and the European Union respectively.

14. The magnitude of changes in imports by the main OECD regions from the Asia- 5 were less significant, with a fall in the value of imports by Japan (largely associated with its own domestic weakness) roughly equal to the combined increase by the United States and European Union. However, these changes mainly reflect corresponding movements in their aggregate imports. Thus, imports coming from the Asia-5 have so far remained relatively stable as a share of total imports for both the United States and European Union, and to a lesser extent Japan (Table 1, lower panel).

15. A number of insights into the OECD's assessments of the scale of the crisis as it evolved over the period are given by Figure 3, which reports the successive estimates of the projected contraction of imports for the main Asia crisis countries and regions, relative to pre-crisis projections. These are based on the published OECD projections of November 1997 and May 1998 (Economic Outlook No.62 and Economic Outlook No.63 ${ }^{11}$ ) and more recent estimates (Economic Outlook No.65).

16. A key feature is that in November 1997, the shock was considered to be confined largely to Indonesia, Malaysia, the Philippines and Thailand, with their combined imports lower by about 8 per cent in 1998, relative to pre-crisis projections. Some slight compression in imports was expected for Korea as well as for China, but largely as a result of regional trade multiplier effects emanating from the Dynamic Asian Economies (DAEs). For the combined region including China, imports were expected to be about 6 to 7 per cent lower in 1998, compared with previous projections of continued robust growth.

17. By March 1998, the Korean domestic economy was itself in major recession, with sharp contractions in domestic demand and output, and imports expected by the OECD to be lower by more than 20 and 30 per cent respectively in 1998 and 1999 relative to pre-crisis levels. At the same time, the estimated scale of the overall reduction in imports for the other Asia- 5 countries was raised substantially, to over 15 per cent for both 1998 and 1999, effectively doubling previous estimates of the size of the trade shock. The estimated impact on China was revised instead only marginally, to be about 5 per cent lower.

18. More recent estimates and projections, based on information available in May 1999, show further significant increases in the estimated scale of the shock in 1998 (as well as in 1999), to over 20 per cent for the region as a whole. This largely reflects further substantial increases in the estimates of the import contractions for Korea and the DAEs in 1998, to around 35 per cent and 25 per cent respectively relative to pre-crisis projections.

10. Official statistics suggest that export volumes in Korea and Thailand rose 47 per cent and 16 per cent, respectively, during the first ten/eleven months of 1998 compared to the same period in 1996. Estimates by J.P. Morgan suggest that export volumes in Indonesia were up over 30 per cent on pre-crisis levels in the first seven months of 1998 and up by at least 20 per cent for the year as a whole in the Philippines.

11. These individual projections were conditional on technical assumptions made at the time concerning macro-policy settings, exchange rates, commodity prices and non-OECD developments, all of which were revised progressively over time. 
19. Looking at the way in which the OECD's forecasts evolved over the same period, Table 2 reports projections and estimates for key macroeconomic aggregates for the three main OECD regions from successive issues of the OECD Economic Outlook. Comparing these over time several features stand out. First, given the progressive deterioration in the outlook for its own domestic demand, Japan was unable to contribute much to the adjustment in the crisis countries. For Japan, the projected net external contribution to growth in 1998 was progressively revised upward from November 1997 to be larger than it was before the crisis broke. Second, in the United States and the European Union, downward revisions to the net external contribution, since November 1997, amount to around $1 / 2$ to $3 / 4$ percentage points for both 1998 and 1999, reflecting to an important extent the impact of the Asia crisis.

20. At the same time, however, the projections for long-term interest rates were revised downward substantially nearly everywhere. This largely reflected declines that were taking place in both policy-controlled and market rates (notably in Autumn 1998), which occurred at least partly in reaction to the Asia crisis. Lower long-term interest rates thus operated (mainly in the United States and Europe) to support domestic demand and offset negative trade effects on activity. In part reflecting these policy adjustments and other factors, which were not wholly unrelated from the emerging-markets crisis ${ }^{12}$ the domestic demand projections were progressively revised upward for Europe and, more substantially, for the United States. Overall, the revisions to growth forecasts and estimates in both these regions since the start of the Asia crisis have now more than offset the impact of the shock.

21. As a guide to the relative importance and impact of the Asia shock on the OECD area, successive forecasts were also informed by simulation analyses using the OECD INTERLINK model, based on estimates of the scale of the shock at the time, i.e. primarily those illustrated in Figure 3. Two such analyses are summarised in Table 3.

22. The first simulation, shown in the upper panel (A) of Table 3, is taken from the OECD's earliest assessment of the crisis, made in November 1997 and later published in Economic Outlook No.62. This basically assumed that the main trade impact would be shared between reductions in non-OECD Asian import growth, relative to the pre-crisis baseline, of 3 to $3 \frac{1}{2}$ per cent and corresponding increases in export volume growth of $1 \frac{1}{2}$ and $2 \frac{1}{2}$ per cent for 1997 and 1998 respectively. Monetary policies were assumed to be set broadly to maintain unchanged real interest rates, implying an easing of nominal short-term interest rates in line with any dis-inflationary effects. No further policy adjustments were assumed within the OECD area, and the Korean economy, like that of other OECD member countries, was assumed to be faced by a purely external shock. Overall the impact on the level of OECD GDP was estimated at -0.3 per cent in 1997 and -0.9 per cent in 1998, implying corresponding slowdowns in GDP growth of $1 / 4$ to $1 / 2$ per cent per annum. Reflecting the regional distribution of international trade, the main impacts were estimated to be largest for Japan and Korea, and roughly twice those for other OECD countries. Without further policy adjustments, the net impact on the current account of the balance of payments was reckoned to be worth about $\$ 40$ billion, but subject to the proviso that with a further slight easing of interest rates within the OECD area, the net impact might be about one-half this amount, with correspondingly smaller effects on trade and growth.

23. The second simulation assessment shown in Table 3, which was made approximately six months later and published in Economic Outlook No.63, is considerably less sanguine. The basic methodology used was similar to that of the previous assessment but took into account a wider range of influences. These included those occurring through the major changes in exchange rates which had taken place by then, major upward revisions to the estimates of direct import compression in the region and, most importantly, the evident scale of the domestic recession in Korea, which this time was included as an exogenous event. At the same time, monetary policies within the OECD area were assumed to adjust more

12. Key amongst these in 1998 were the "safe haven" reactions of investments and capital flows to the mid-year deepening of the emerging-markets crisis and associated financial tensions, and the strength of stock markets. 
aggressively (as they were in the process of doing) to ease short-term real interest rates in the United States and Europe by $1 / 2$ per cent. Given the already low levels of interest rates in Japan, nominal interest rates there were assumed to be unchanged.

24. The net result of these various revisions, reported in the lower panel (B) of Table 3, was to raise the initial estimates of the impact on total OECD growth in 1998 to around $3 / 4$ per cent $(1 / 2$ per cent excluding Korea) compared with the earlier estimate of about $1 / 2$ per cent. The net impact on OECD current accounts (excluding Korea) was estimated at about $\$ 50$ and 90 billions in 1998 and 1999 respectively, spread evenly between the United States, Japan and the European Union. Overall, the easing of monetary policies in the OECD area was seen to moderate the net impact on GDP growth, which was nonetheless lower than otherwise projected. As before, the major impacts on growth were seen for Japan and other OECD Pacific area countries, given their close trading ties with the crisis economies.

25. The simulation reported in Table 4 follows broadly the same procedures as those described above, but takes the assessment a stage further by including in it the most recently-available estimates of the scale and distribution of the Asian trade shock in 1998 and beyond. Thus it comes closest to being a full ex-post evaluation of the implications of the Asia shock for the OECD countries. On this basis, reflecting the further upward revisions to the scale of the demand and import contraction within nonOECD Asia, the estimate of the net effect on OECD growth in 1998 is further raised to around 11/4 per cent (1 per cent excluding Korea), with further substantial revisions to the impact on Japan. The corresponding impact on inflation is seen to reduce it slightly, whilst estimates of the effect on OECD current accounts (excluding Korea) are revised substantially upward in line with activity, to around $\$ 100$ billion, in both 1998 and 1999. On this basis, the overall impact on world trade growth in 1998 is reckoned to be about $51 / 4$ per cent.

26. Thus the overall picture is that, although the OECD assessment of the impact of the crisis at the end of 1997 was qualitatively correct, the scale of the Asia shock and its consequences for the OECD region was significantly underestimated. Nonetheless, the picture is less clear from the point of view of unconditional forecast accuracy, given the influences of other factors, which largely worked in the opposite direction for the United States and, to a lesser extent, the European economies as evidenced by the evolution of the forecasts presented in Table 2 .

\section{Assessing the assessment}

27. Given the pervading influence of other factors influencing the world economy over the period, the above analysis is clearly insufficient to provide a systematic analysis of the predictive accuracy or usefulness of econometric models used in assessing the crisis effects. On the one hand, the most important exogenous inputs, those related to the size of the shocks, were substantially underestimated. On the other hand, the direct effects were swamped by other residual influences in the forecast. This raises the interesting question of how accurate the model-based analyses and corresponding projections for the OECD would have been had more accurate information been available at the time.

28. To investigate this issue further, a series of simulations and alternative scenarios have been constructed using INTERLINK on the basis of the OECD projections as they were in November 1997 (Economic Outlook No.62), before the full crisis broke, controlling for differences in a variety of exogenous assumptions. In building up such a picture, it is possible to see how accurate the assessment might have been had it been better informed and what the main influential factors were. ${ }^{13}$

13. The scenario-based approach used here is similar to that presented in the general assessment of downside risks in Economic Outlook No.64, and the broad methodology advocated by Don (1998). 
29. Tables 5 and 6 report the results of such an exercise based on a sequential analysis of key identifiable Asia and non-Asia exogenous factors, measured in relation to the Economic Outlook No.62 forecast. These concern five main elements:

- the Asia shock itself, comprising the main elements identified as inputs to the simulation reported previously in Table 4, but measured in relation to the Economic Outlook No.62 baseline forecast for 1998;

- differences in exchange rate assumptions within the OECD area - yen and Euro depreciations against the US dollar of $71 / 2$ and 1 per cent respectively;

- differences in stock markets, which were respectively 20 and 40 per cent higher than anticipated for the United States and major European markets and 20 per cent lower than expected for Japan;

- differences in real interest rates;

- and differences in commodity prices, lower by 31 and 16 per cent for oil and non-oil commodities respectively (though in part crisis-related, it is useful to treat these as a separate influence).

30. As shown in Table 5, the Asia shock accounts for a reduction in GDP in 1998 of just over 1 per cent, with its largest effects on the two OECD Asian countries. The influence of interest rates is also negative (since real rates proved to be higher than expected) but relatively small. Apart from Japan, the stock-market effect is positive throughout and quite significant for the United States and the other OECD economies. The effects of lower-than-expected oil and commodity prices are also mildly stimulative, whilst those of subsequent exchange-rate movements are broadly neutral for the OECD area, serving largely to redistribute trade and activity effects between the United States and Japan. The final column of Table 5 adds together these components, to provide estimates of the combined effect of differences in all these assumptions, relative to those made in Economic Outlook No.62, on the projections for main OECD aggregates for 1998 .

31. In Table 6, these simulated effects (column 2) are combined with the original Economic Outlook No.62 projections (column 1) to give a revised scenario for 1998 (column 3) based on the revised exogenous assumptions. These results are then compared with the most recent estimates of outturns for 1998 (column 4) to give a set of residuals in the final column. From these comparisons, a number of points are evident.

32. Firstly, the overall projection error for OECD area growth is relatively small but positive at a little under $1 / 4$ per cent, implying a slightly more favourable outcome than expected. For the OECD area excluding Korea, the prediction error is negligible. Nonetheless, there are significant differences in allocation across the main OECD zones, with growth in Europe and the United States (more so) stronger than expected and in Japan much weaker. Looking at contributory factors, these differences are seen to be largely associated with corresponding differences in domestic demand which, in turn, have reflected influences also related to the emerging-markets crisis. ${ }^{14}$ The corresponding residual on growth in world trade is negative at around $3 / 4$ per cent, implying a slightly lower-than-expected out-turn, but the error is small in relation to the size of the shock and the sharp deceleration which was taking place through the period.

33. On the whole, the results for inflation are mixed, with out-turns which are more favourable for the United States and less favourable for the other OECD countries. Overall, inflation for the area is underestimated by about $1 / 4$ per cent.

14. See footnote 12 . 
34. For the current-account balances, the overall residual is relatively small at $\$-7$ billion ( $\$-2$ billion excluding Korea) in relation to both the scale of movements involved and the scale of measurement errors commonly associated with balance-of-payments current-account statistics. ${ }^{15}$ The distribution of effects is, however, less accurate with out-turns for Japan and Europe, respectively, more and less positive by fairly significant amounts.

35. The overall conclusion is that such a model-based assessment would have provided a reasonably accurate picture for the main OECD aggregates had it been more accurately informed in terms of exogenous assumptions, although there are significant differences in regional composition. Most notably amongst these are much stronger domestic demand for the United States and much weaker domestic demand for Japan. One might speculate further on the extent to which these differences are also not in some way a reflection of Asia effects not accounted for in the analysis. For Japan, for example, they in part reflect the effects of financial expectations and balance-sheet restructuring associated with the ongoing recession in the region, neither of which are easily captured by models. For the United States, "safe haven" effects and stimulatory monetary policies associated with the crisis also clearly had a positive influence on investments and stock markets, which, in turn, acted as a stimulus to domestic demand.

36. From a policy perspective, a number of important lessons are clear. First, the initial underestimation of the scale of the crisis and its effects on the rest of the world economy reflected in good part the lack of recognition of the importance of international capital flows, as opposed to trade flows. Secondly, substantial credit-market inefficiencies, both in the Asia-5 region and in Japan, played an important role in amplifying the effects of the initial financial shocks on the real side of the economies. Thirdly, confidence effects in financial markets interacted with major balance-sheets adjustments of institutional investors leading to the international transmission of contagion, thus calling for monetary policy responses also far from the main crisis countries themselves. Overall, more timely and better-informed surveillance and analysis of potential crisis economies is called for, also in the collective interest to avoid both excessive capital inflows and increase the available information necessary for investment decisions. At the same time, greater attention needs to be given to the transmission of financial impulses through portfolio, credit and market confidence effects hand, particularly in the use of models that attempt to evaluate the international consequences of such country or area-specific shocks.

15. For example, the corresponding measurement discrepancy on world current-account balances has been of the order of $\$ 60$ to $\$ 100$ billions over the last four or five years. 
ECO/WKP(2000)9

\section{BIBLIOGRAPHY}

DON F.J.H., (1998), "Forecasting in Macroeconomics: A Practitioners' View", CPB Netherlands Bureau of Economic Policy Analysis Working Paper (preliminary version).

OECD (1999a), "OECD Economic Projections”, OECD Economic Policy Brief, OECD Observer series, June 1999.

OECD (1999b), OECD Economic Outlook No.65, June 1999.

OECD (1998), OECD Economic Outlook No.63, June 1998.

OECD (1997), OECD Economic Outlook No.62, December 1997.

RICHARDSON P., C. GIORNO, D. TURNER and D. RAE (1999) "An overview of the OECD INTERLINK model”, OECD Economics Department Working Paper, forthcoming.

RICHARDSON P. (1998), "The structure and simulation properties of OECD's INTERLINK model, OECD Economic Studies, No.10.

TURNER D., P. RICHARDSON and S. RAUFFET (1996), "Modelling the supply side of the seven major economies", OECD Economics Department Working Paper No.167. 
ECO/WKP(2000)9

Table 1. Trade adjustment of the major OECD regions with the Asia-5 ${ }^{a}$

\begin{tabular}{|c|c|c|c|c|c|c|}
\hline \multirow{2}{*}{ Trade balance: } & \multirow{2}{*}{ with: } & \multicolumn{3}{|c|}{ Value \$US billion } & \multicolumn{2}{|c|}{ Absolute change 1996-98 } \\
\hline & & 1996 & 1997 & 1998 & value $\$$ US billion & as per cent of GDP \\
\hline OECD & Asia-5 & 14.7 & 2.8 & -69.6 & -84.3 & -0.4 \\
\hline \multirow[t]{3}{*}{ United States } & Asia-5 & -15.8 & -18.3 & -37.9 & -22.1 & -0.2 \\
\hline & World & -168.8 & -183.0 & -233.8 & -65.1 & -0.5 \\
\hline & World as per cent of GDP & -2.2 & -2.3 & -2.7 & & \\
\hline \multirow[t]{3}{*}{ Japan } & Asia-5 & 22.8 & 18.9 & 1.4 & -21.4 & -0.5 \\
\hline & World & 61.6 & 82.2 & 107.3 & 45.7 & 1.5 \\
\hline & World as per cent of GDP & 1.3 & 2.0 & 2.8 & & \\
\hline \multirow[t]{3}{*}{ European Union } & Asia-5 & 1.0 & -0.9 & -26.4 & -27.3 & -0.3 \\
\hline & World & 25.3 & 29.6 & -5.8 & -31.1 & -0.4 \\
\hline & World as per cent of GDP & 0.3 & 0.4 & -0.1 & & \\
\hline \multirow{2}{*}{ Exports of: } & \multirow{2}{*}{ to: } & \multicolumn{3}{|c|}{ Value \$US billion } & \multicolumn{2}{|c|}{ Change 1996-98 } \\
\hline & & 1996 & 1997 & 1998 & absolute & percentage \\
\hline OECD & Asia-5 & 203.8 & 198.2 & 126.6 & -77.2 & -37.9 \\
\hline \multirow{3}{*}{ United States } & Asia-5 & 52.4 & 55.2 & 39.8 & -12.6 & -24.1 \\
\hline & World & 622.9 & 687.9 & 680.6 & 57.7 & 9.3 \\
\hline & Asia-5 as per cent of World & 8.4 & 8.0 & 5.8 & -2.6 & \\
\hline \multirow[t]{3}{*}{ Japan } & Asia-5 & 80.4 & 74.1 & 45.6 & -34.8 & -43.2 \\
\hline & World & 410.9 & 421.2 & 387.9 & -22.9 & -5.6 \\
\hline & Asia-5 as per cent of World & 19.6 & 17.6 & 11.8 & -7.8 & \\
\hline \multirow[t]{3}{*}{ European Union } & Asia-5 & 49.7 & 48.4 & 28.1 & -21.6 & -43.4 \\
\hline & World & 752.9 & 781.1 & 777.6 & 24.6 & 3.3 \\
\hline & Asia-5 as per cent of World & 6.6 & 6.2 & 3.6 & -3.0 & \\
\hline \multirow{2}{*}{ Imports of: } & \multirow{2}{*}{ from: } & \multicolumn{3}{|c|}{ Value \$US billion } & \multicolumn{2}{|c|}{ Change 1996-98 } \\
\hline & & 1996 & 1997 & 1998 & absolute & percentage \\
\hline OECD & Asia-5 & 189.1 & 195.4 & 196.2 & 7.1 & 3.7 \\
\hline \multirow[t]{3}{*}{ United States } & Asia-5 & 68.2 & 73.5 & 77.7 & 9.5 & 13.9 \\
\hline & World & 791.7 & 870.9 & 914.4 & 122.8 & 15.5 \\
\hline & Asia-5 as per cent of World & 8.6 & 8.4 & 8.5 & -0.1 & \\
\hline \multirow[t]{3}{*}{ Japan } & Asia-5 & 57.6 & 55.2 & 44.3 & -13.4 & -23.2 \\
\hline & World & 349.3 & 339.0 & 280.6 & -68.6 & -19.6 \\
\hline & Asia-5 as per cent of World & 16.5 & 16.3 & 15.8 & -0.7 & \\
\hline \multirow[t]{3}{*}{ European Union } & Asia-5 & 48.7 & 49.4 & 54.5 & 5.7 & 11.8 \\
\hline & World & 727.6 & 751.5 & 783.3 & 55.7 & 7.7 \\
\hline & Asia-5 as per cent of World & 6.7 & 6.6 & 7.0 & 0.3 & \\
\hline
\end{tabular}

a) Asia-5 refers to Korea, Malaysia, the Philippines, Thailand and Indonesia. Figures refer to trade in merchandise goods only.

Source: OECD, Monthly Statistics of Foreign Trade. 
Table 2. The changing outlook as the Asia crisis evolved ${ }^{a}$

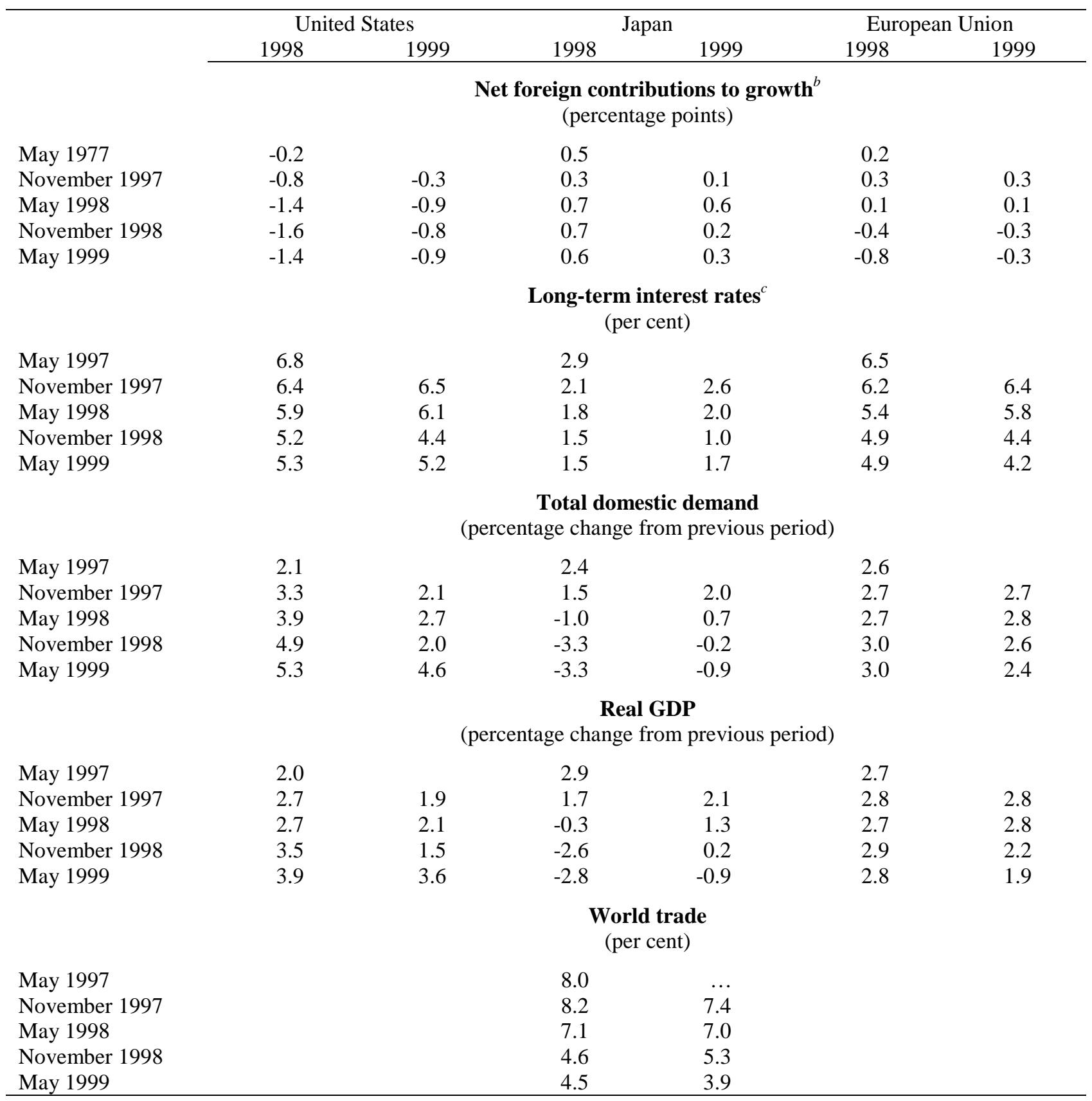

a) Dates in the left-hand column refer to the completion dates of the projections reported in OECD Economic Outlook Nos.61, $62,63,64$ and 65 .

b) Net exports contributions to changes in real GDP (as a percentage of real GDP in the previous year).

c) Unweighted average of Germany, France, Italy and the United Kingdom for the European Union. 
ECO/WKP(2000)9

Table 3. Successive assessments of the effects of the crisis in emerging Asia on OECD

A)

OECD Economic Outlook No.62

Potential macroeconomic impact of the Southeast-Asian financial turbulence on the OECD area $^{a}$ percentage deviation from baseline

\begin{tabular}{lcc|cc|ccc}
\hline & \multicolumn{2}{c|}{ Real GDP level } & \multicolumn{2}{c|}{ Net exports $^{b}$} & \multicolumn{2}{c}{ Inflation $^{c}$} \\
& 1997 & 1998 & 1997 & 1998 & 1997 & -0.3 \\
United States & -0.3 & -0.7 & -0.1 & -0.3 & 0.0 & -0.9 \\
Japan & -0.6 & -1.4 & -0.2 & -0.5 & 0.0 & -0.3 \\
European Union & -0.3 & -0.8 & -0.2 & -0.5 & 0.0 & -0.5 \\
Korea, Australia, New Zealand & -0.5 & -1.4 & -0.3 & -0.7 & -0.1 & -0.5 \\
Total OECD & $\mathbf{- 0 . 3}$ & $\mathbf{- 0 . 9}$ & $\mathbf{- 0 . 2}$ & $\mathbf{- 0 . 5}$ & $\mathbf{0 . 0}$ & $\mathbf{- 0 . 5}$ \\
\hline
\end{tabular}

a) Nominal exchange rates and real interest rates in OECD countries are assumed to be unchanged.

b) Goods and services; contribution to the change in the level of GDP in percentage points.

c) Change in the private consumption deflator.

- For non-OECD Asia: import volume growth lower by 3 per cent and 31/2 per cent and export volume growth higher by $1 \frac{1 / 2}{2}$ per cent and 21/2 per cent in 1997 and 1998 respectively. Export prices in \$US terms are 11/2 per cent lower in 1997 and a further 2 per cent lower in 1998. Overall impact on OECD current balances equivalent to a \$US 40 billion per annum deterioration (without further monetary policy action).

Source: OECD Economic Outlook No.62, December, 1997

B)

OECD Economic Outlook No.63

Effects of the crisis in emerging Asia on OECD countries in 1998 and 1999 deviations from scenario involving no crisis in Asia

\begin{tabular}{|c|c|c|c|c|c|}
\hline & \multicolumn{2}{|c|}{$\begin{array}{l}\text { Real GDP growth } \\
\text { (per cent) }\end{array}$} & \multirow{2}{*}{$\begin{array}{c}\text { Real GDP level } \\
\text { (per cent) } \\
1999\end{array}$} & \multicolumn{2}{|c|}{$\begin{array}{l}\text { Current account } \\
\text { (\$US billion) }\end{array}$} \\
\hline & 1998 & 1999 & & 1998 & 1999 \\
\hline United States & -0.4 & -0.4 & -0.8 & -13 & -27 \\
\hline Japan & -1.3 & -0.7 & -2.0 & -12 & -22 \\
\hline European Union & -0.4 & -0.2 & -0.6 & -19 & -28 \\
\hline Canada & -0.2 & -0.3 & -0.5 & -2 & -3 \\
\hline Australia and New Zealand & -0.9 & -0.1 & -1.0 & -3 & -4 \\
\hline Total OECD, excluding Korea & -0.5 & -0.3 & -0.8 & -53 & -90 \\
\hline Korea & -6.8 & -2.6 & -9.2 & +28 & +34 \\
\hline Total OECD & -0.7 & -0.4 & -1.1 & -26 & -55 \\
\hline
\end{tabular}

The key assumptions underlying the above alternative scenario are:

- the exchange rates of the four ASEAN crisis countries and Korea are maintained at their pre-crisis levels;

- the absence of any import compression, which is estimated on the basis of the May 1997 medium-term reference scenario reported in OECD Economic Outlook No.61 to be 23 per cent in Korea and 141/2 per cent in the other crisis countries in 1998, and 34 and 18 per cent, respectively, in 1999;

- real interest rates are $1 / 2$ percentage point higher in the OECD countries in both 1998 and 1999, except in Japan where nominal interest rates are assumed to be unaffected by the crisis.

Source: OECD Economic Outlook No.63, June 1998. 
Table 4. Effects of the crisis in emerging Asia on OECD countries in 1998 and 1999 per cent deviations from scenario including no crisis in Asia

\begin{tabular}{|c|c|c|}
\hline & 1998 & 1999 \\
\hline & \multicolumn{2}{|c|}{ Real GDP growth } \\
\hline United States & -0.8 & -0.4 \\
\hline Japan & -2.7 & -0.7 \\
\hline EEC & -0.7 & -0.3 \\
\hline Total OECD, excluding Korea & -1.0 & -0.4 \\
\hline Korea & -13.2 & -2.1 \\
\hline \multirow[t]{2}{*}{ Total OECD } & -1.3 & -0.4 \\
\hline & \multicolumn{2}{|c|}{ Inflation (GDP deflator) } \\
\hline United States & -0.2 & -0.8 \\
\hline Japan & -0.2 & -1.5 \\
\hline EEC & -0.1 & -0.8 \\
\hline Total OECD, excluding Korea & -0.2 & -0.9 \\
\hline Korea & 0.1 & -1.2 \\
\hline \multirow[t]{2}{*}{ Total OECD } & -0.2 & -0.9 \\
\hline & \multicolumn{2}{|c|}{ Domestic demand growth } \\
\hline United States & -0.3 & -0.1 \\
\hline Japan & -1.9 & -0.5 \\
\hline EEC & -0.2 & -0.2 \\
\hline Total OECD, excluding Korea & -0.2 & -0.2 \\
\hline Korea & -32.5 & 0.9 \\
\hline \multirow[t]{2}{*}{ Total OECD } & -0.9 & -0.2 \\
\hline & \multicolumn{2}{|c|}{ Current balance (\$US) } \\
\hline United States & -20.4 & -34.9 \\
\hline Japan & -22.1 & -30.9 \\
\hline EEC & -33.9 & -25.8 \\
\hline Total OECD, excluding Korea & -90.9 & -107.4 \\
\hline Korea & 55.5 & 40.0 \\
\hline Non-OECD emerging Asia (excluding China) & 59.3 & 73.1 \\
\hline \multirow[t]{3}{*}{ Other non-OECD (including China) } & -23.9 & -5.7 \\
\hline & \multicolumn{2}{|c|}{ World trade growth } \\
\hline & -5.3 & -0.4 \\
\hline
\end{tabular}


ECO/WKP(2000)9

Table 5. Simulated effects of key developments since Autumn 1997 on the projections for $1^{1998}{ }^{a}$ per cent differences from the OECD Economic Outlook No.62 projections

\begin{tabular}{|c|c|c|c|c|c|c|}
\hline & $\begin{array}{l}\text { Stronger-than- } \\
\text { expected shock in } \\
\text { Asian emerging } \\
\text { markets }\end{array}$ & $\begin{array}{c}\text { OECD } \\
\text { exchange rate } \\
\text { adjustment }^{c}\end{array}$ & $\begin{array}{l}\text { Stock market } \\
\text { shock }^{d}\end{array}$ & $\begin{array}{l}\text { Real interest } \\
\text { rates } \\
\text { adjustment }^{e}\end{array}$ & $\begin{array}{c}\text { Oil and } \\
\text { commodity } \\
\text { price shock }\end{array}$ & Total \\
\hline & [1] & {$[2]$} & {$[3]$} & {$[4]$} & {$[5]$} & $\begin{array}{c}{[1]+[2]+[3]+} \\
{[4]+[5]}\end{array}$ \\
\hline \multicolumn{7}{|l|}{ Real GDP level } \\
\hline $\begin{array}{l}\text { United States } \\
\text { Japan } \\
\text { European Union } \\
\text { Korea } \\
\text { OECD } \\
\text { OECD less Korea }\end{array}$ & $\begin{array}{r}-0.8 \\
-1.9 \\
-0.6 \\
-12.1 \\
-1.1 \\
-0.8\end{array}$ & $\begin{array}{r}-0.3 \\
0.3 \\
0.0 \\
-0.5 \\
0.0 \\
0.0\end{array}$ & $\begin{array}{l}0.6 \\
0.0 \\
0.3 \\
0.3 \\
0.4 \\
0.4\end{array}$ & $\begin{array}{r}-0.2 \\
-0.2 \\
-0.1 \\
0.0 \\
-0.1 \\
-0.1\end{array}$ & $\begin{array}{l}0.1 \\
0.4 \\
0.1 \\
0.4 \\
0.1 \\
0.1\end{array}$ & $\begin{array}{r}-0.5 \\
-1.4 \\
-0.3 \\
-11.9 \\
-0.8 \\
-0.5\end{array}$ \\
\hline \multicolumn{7}{|l|}{ GDP deflator level } \\
\hline $\begin{array}{l}\text { United States } \\
\text { Japan } \\
\text { European Union } \\
\text { Korea } \\
\text { OECD } \\
\text { OECD less Korea }\end{array}$ & $\begin{array}{r}-0.2 \\
-0.1 \\
-0.1 \\
2.4 \\
-0.1 \\
-0.1\end{array}$ & $\begin{array}{r}-0.2 \\
0.1 \\
0.0 \\
-0.1 \\
0.0 \\
0.0\end{array}$ & $\begin{array}{l}0.1 \\
0.0 \\
0.0 \\
0.0 \\
0.1 \\
0.1\end{array}$ & $\begin{array}{r}-0.1 \\
0.0 \\
0.0 \\
0.0 \\
0.0 \\
0.0\end{array}$ & $\begin{array}{l}-0.2 \\
-0.6 \\
-0.6 \\
-0.7 \\
-0.5 \\
-0.5\end{array}$ & $\begin{array}{r}-0.4 \\
-0.7 \\
-0.7 \\
1.7 \\
-0.5 \\
-0.5\end{array}$ \\
\hline \multicolumn{7}{|c|}{ Total domestic demand level } \\
\hline $\begin{array}{l}\text { United States } \\
\text { Japan } \\
\text { European Union } \\
\text { Korea } \\
\text { OECD } \\
\text { OECD less Korea }\end{array}$ & $\begin{array}{r}-0.5 \\
-1.3 \\
-0.3 \\
-22.4 \\
-1.0 \\
-0.5\end{array}$ & $\begin{array}{r}-0.1 \\
0.1 \\
0.0 \\
-0.2 \\
0.0 \\
0.0\end{array}$ & $\begin{array}{r}0.9 \\
-0.2 \\
0.3 \\
0.2 \\
0.4 \\
0.4\end{array}$ & $\begin{array}{r}-0.2 \\
-0.2 \\
-0.1 \\
0.0 \\
-0.2 \\
-0.2\end{array}$ & $\begin{array}{l}0.2 \\
0.5 \\
0.2 \\
0.8 \\
0.3 \\
0.2\end{array}$ & $\begin{array}{r}0.3 \\
-1.1 \\
0.2 \\
-21.7 \\
-0.5 \\
0.0\end{array}$ \\
\hline \multicolumn{7}{|c|}{ Current balance (\$US billion) } \\
\hline $\begin{array}{l}\text { United States } \\
\text { Japan } \\
\text { European Union } \\
\text { Korea }\end{array}$ & $\begin{array}{r}-14.1 \\
-19.9 \\
-20.8 \\
50.1\end{array}$ & $\begin{array}{r}4.5 \\
-5.2 \\
-1.3 \\
0.7\end{array}$ & $\begin{array}{r}-18.5 \\
7.6 \\
3.0 \\
0.2\end{array}$ & $\begin{array}{r}4.4 \\
-0.3 \\
-1.9 \\
0.0\end{array}$ & $\begin{array}{r}7.1 \\
12.1 \\
9.5 \\
2.1\end{array}$ & $\begin{array}{r}-16.5 \\
-5.7 \\
-11.5 \\
53.2\end{array}$ \\
\hline $\begin{array}{l}\text { OECD total } \\
\text { OECD less Korea }\end{array}$ & $\begin{array}{l}-15.7 \\
-65.8\end{array}$ & $\begin{array}{l}2.7 \\
2.0\end{array}$ & $\begin{array}{l}-5.1 \\
-5.3\end{array}$ & $\begin{array}{l}2.2 \\
2.2\end{array}$ & $\begin{array}{l}12.3 \\
10.2\end{array}$ & $\begin{array}{r}-3.6 \\
-56.8\end{array}$ \\
\hline World trade level & -4.1 & 0.0 & 1.0 & -0.4 & 0.5 & -3.0 \\
\hline
\end{tabular}

a) All simulations assume unchanged real government expenditures and unchanged real interest rates, except for simulation [4], as mentioned in footnote e.

b) For non-OECD Asian emerging markets and Korea, import volumes are, on average, 16 per cent lower. Export volumes and import and export prices in dollar terms are also slightly lower, implying an overall improvement in the combined current account for the region of \$US 90 billion.

c) Relative to the US dollar, the yen is $71 \frac{1}{2}$ per cent lower and EU exchange rates are, on average, 1 per cent lower.

d) Stock market prices are respectively 20 per cent and 40 per cent higher for the United States and major European economies, and 20 per cent lower for Japan.

e) Real short-term and long-term interest rates are respectively 0.7 and 0.3 percentage points higher for the United States, 0.5 percentage points higher and 0.3 percentage points lower for the Euro area and 0.2 percentage points higher and 0.9 percentage points lower for the United Kingdom. For Japan, real short-term interest rates are 0.7 percentage points higher, with real long-term rates unchanged.

f) Crude oil and other commodity prices are, respectively, 31 per cent and 16 per cent lower. 
Table 6. Comparisons of “adjusted” OECD Economic Outlook No.62 projections with out-turns for 1998

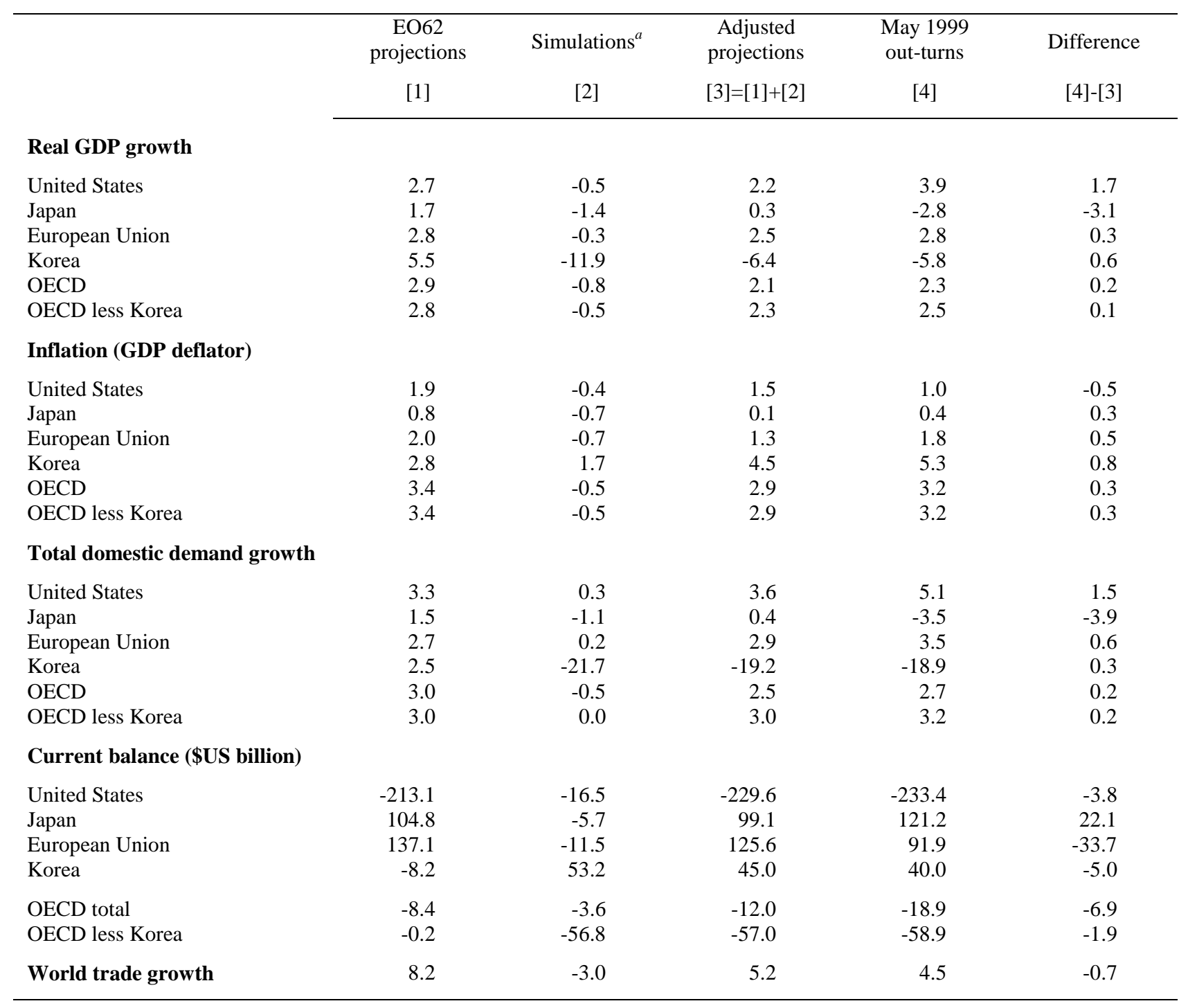

a) Simulation as final column of Table 5 . 
ECO/WKP(2000)9

Figure 2. Adjustment of the trade balance of the Asia-5, 1996-98

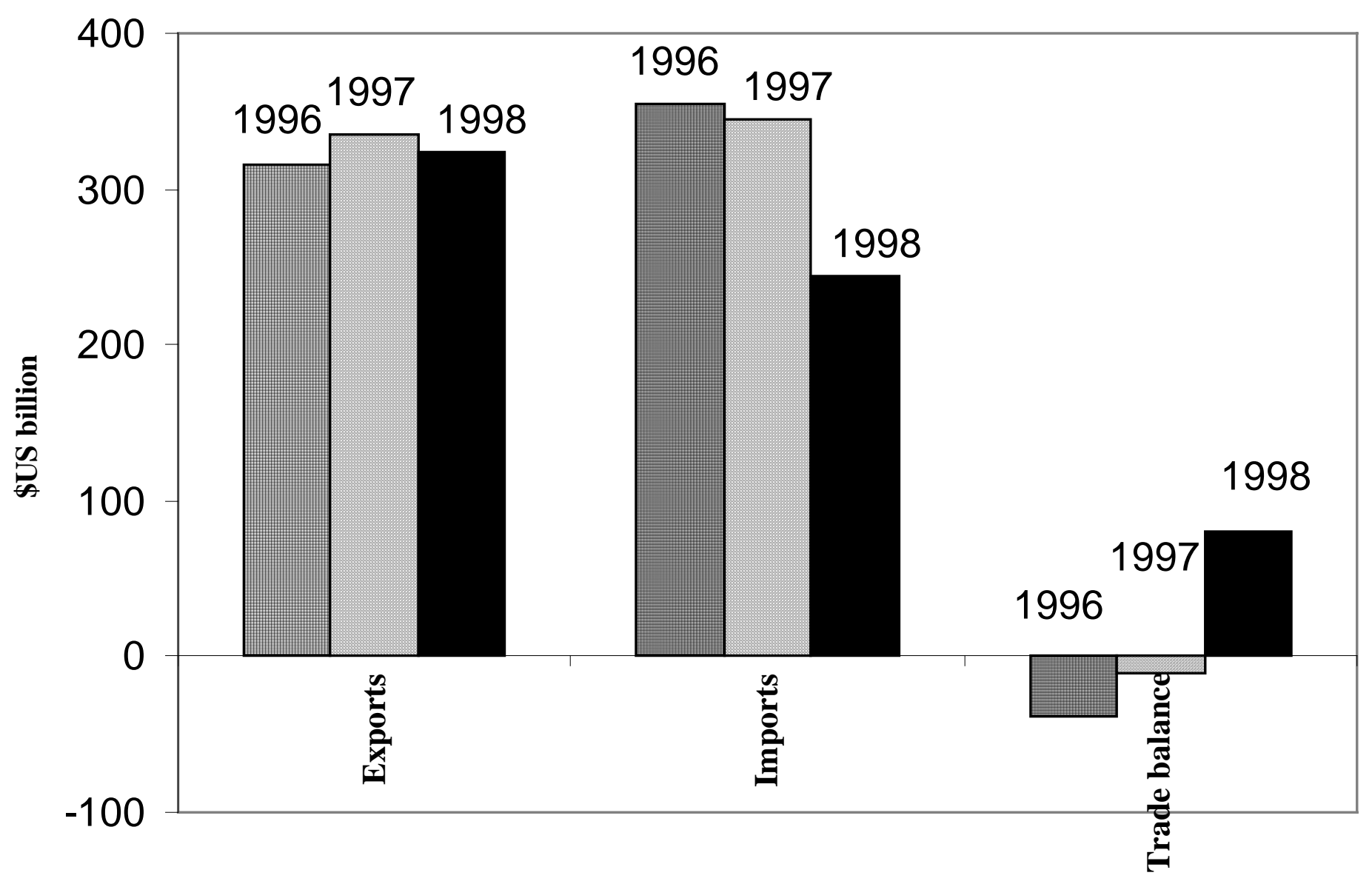


Figure 3. Changes in assessment of the Asian crisis since November $1997^{\mathrm{a}}$ per cent differences from alternative pre-crisis projections

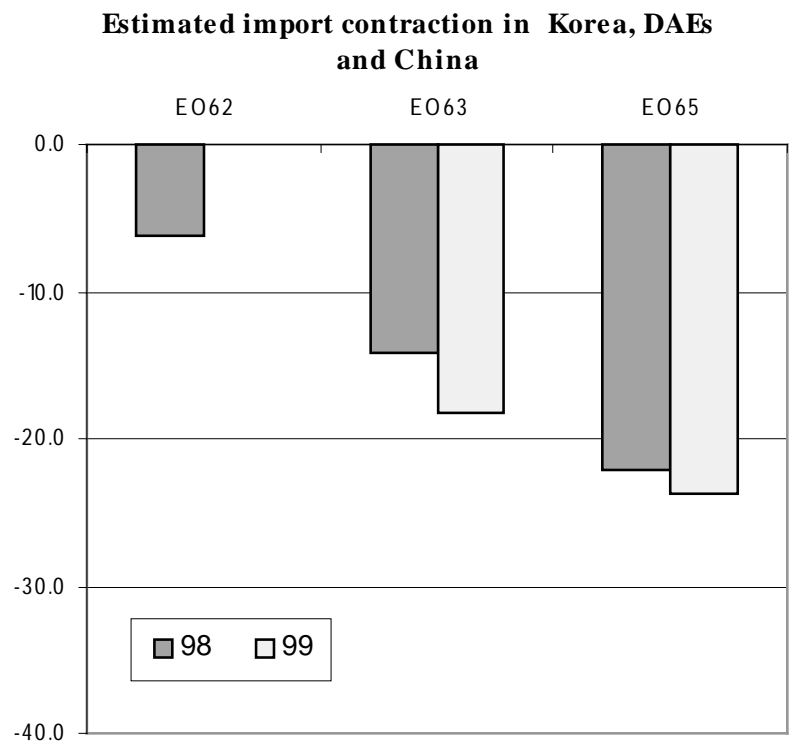

Estimated import contraction in China

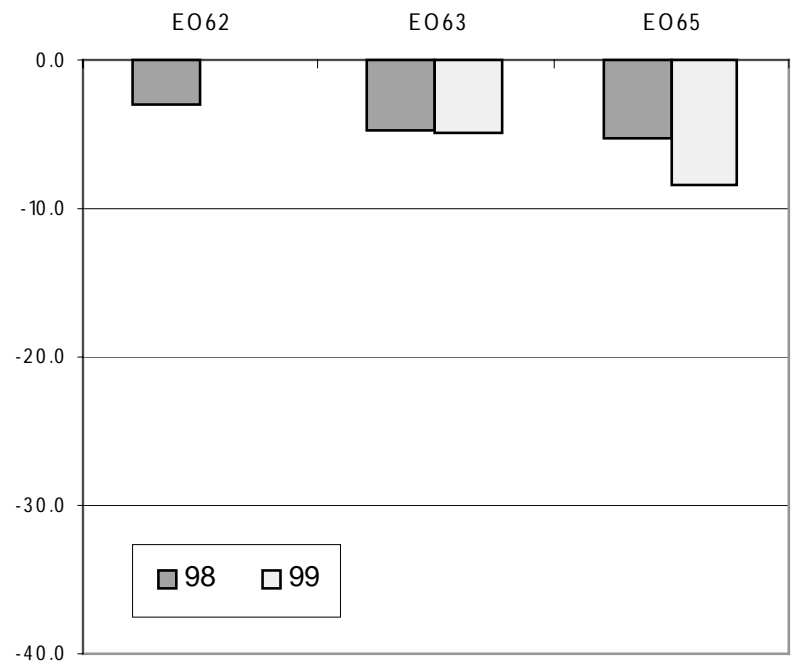

Estimated import contraction in Korea

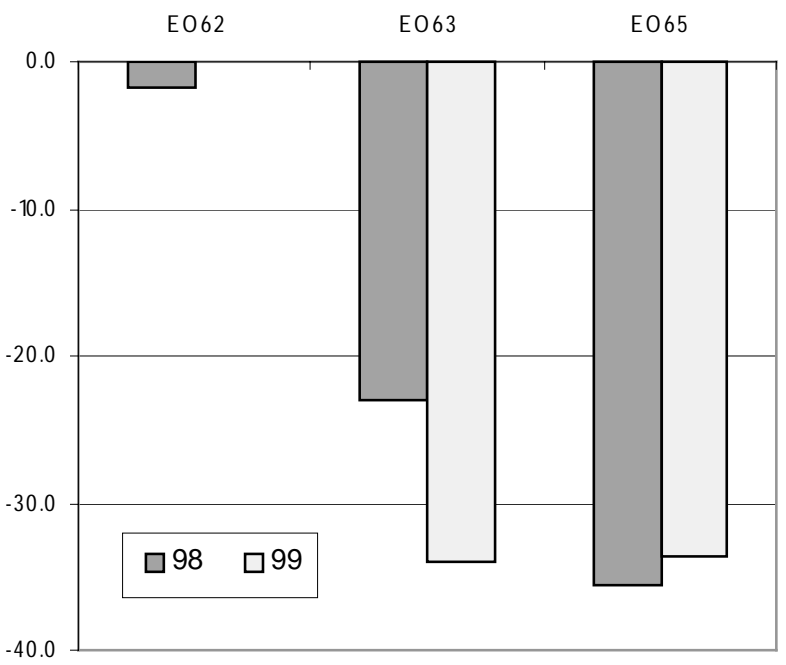

Estimated import contraction in the DAEs

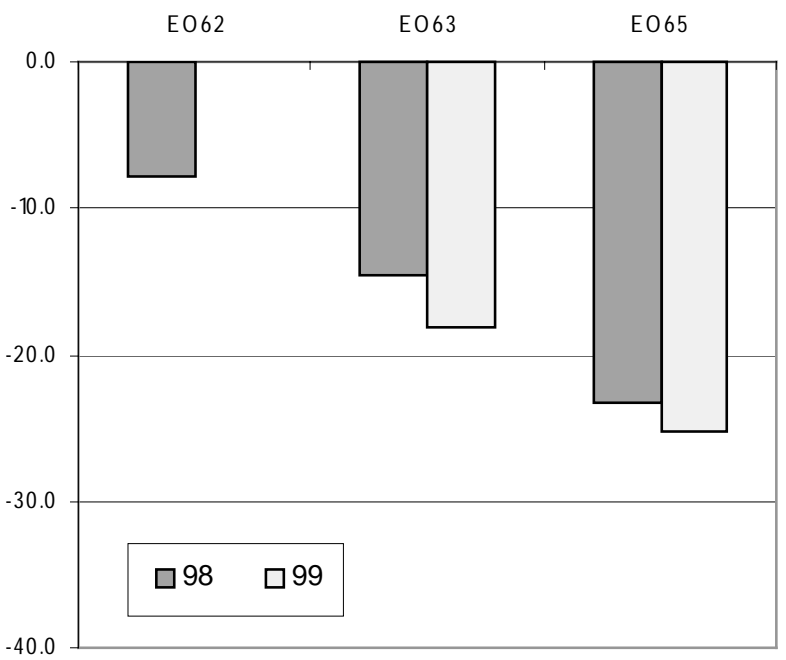

${ }^{\text {a }}$ Based on regional projections as published in OECD Economic Outlook Nos. 61, 62, 63 and 65. 


\section{ECONOMICS DEPARTMENT WORKING PAPERS}

235. Modelling manufacturing export volumes equations

A system estimation approach

(April 2000) Keiko Murata, Dave Turner, Dave Rae and Laurence Le Fouler

234. The Polish Tax Reform

(March 2000) Patrick Lenain and Leszek Bartoszuk

233. The tax system in Mexico : a need for strengthening the revenue raising capacity

(March 2000) Thomas Dalsgaard

232. EMU, the Euro and the European policy mix

(February 2000) Jonathan Coppel, Martine Durand and Ignazio Visco

231. The tax system in Japan: a need for comprehensive reform

(February 2000) Thomas Dalsgaard and Masaaki Kawagoe

230. The size and role of automatic fiscal stabilisers in the 1990s and beyond (January 2000) Paul van den Noord

229. Enhancing environmentally sustainable growth in Finland (January 2000) Ann Vourc'h and Miguel Jimenez

228. Finance and growth: Some theoretical considerations, and a review of the empirical literature (January 2000) Kotaro Tsuru

227. What the yield curves say about inflation: Does it change over time? (December 1999) Sebastian T. Schich

226. Summary Indicators of Product Market Regulation with an Extension to Employment Protection Legislation

(December 1999) Giuseppe Nicoletti, Stefano Scarpetta and Olivier Boylaud

225. Some Issues Related to the Equity-Efficiency Trade-Off in the Swedish Tax and Transfer System (November 1999) Henning Strand

224. The Economic Effects of Employment-Conditional Income Support Schemes for the Low-Paid: An Illustration from a CGE Model Applied to Four OECD Countries

(October 1999) Andrea Bassanini, Jørn Henrik Rasmussen and Stefano Scarpetta

223. The Use of Financial Market Indicators by Monetary Authorities (September 1999) Paul Mylonas and Sebasian Schich

222. Tax Reform in Switzerland

(August 1999) David Carey, Kathryn Gordon and Philippe Thalman

221. Trends in Market Openness

(August 1999) Jonathan Coppel and Martine Durand 
220. Technology Upgrading with Learning Cost : A Solution for Two "Productivity Puzzles" (July 1999) Sanghoon Ahn

219. Testing for a Common OECD Phillips Curve (July 1999) Dave Turner and Elena Seghezza

218. Sustainable Economic Growth: Natural Resources and the Environment (July 1999) Paul van den Noord and Ann Vourc'h

217. Coping with Population Ageing in Australia (July 1999) David Carey

216. Estimating Prudent Budgetary Margins for 11 EU Countries : A Simulated SVAR Model Approach (July 1999) Thomas Dalsgaard and Alain de Serres

215. The Problems and Prospects Faced by Pay-As-You-Go Pension Systems : A Case Study of Greece (June 1999) Paul Mylonas and Christine de la Maisonneuve

214. Greek Public Enterprises: Challenges for Reform (May 1999) Paul Mylonas and Isabelle Joumard

213. The Levels and Cyclical Behaviour of Mark-Ups Across Countries and Market Structures (May 1999) Joaquim Oliveira Martins and Stefano Scarpetta

212. Poverty Dynamics in Four OECD Countries (April 1999) Pablo Antolín, Thai-Thanh Dang and Howard Oxley Assisted by Ross Finnie and Roger Sceviour

211. The Recent Experience with Capital Flows to Emerging Market Economies (February 1999) Sveinbjörn Blöndal and Hans Christiansen

210. Foreign Portfolio Investors Before and During a Crisis (February 1999) Woochan Kim and Shang-Jin Wei

209. Towards More Efficient Government: Reforming Federal Fiscal Relations in Germany (February 1999) Eckhard Wurzel

208. Stock Market Fluctuations and Consumption Behaviour : Some Recent Evidence (December 1998) Laurence Boone, Claude Giorno and Pete Richardson

207. Microeconometric analysis of the retirement decision: The Netherlands (June 1998) Maarten Lindeboom

206. Microeconometric analysis of the retirement decision: United Kingdom (June 1998) Raffaele Miniaci and Elena Stancanelli

205. Microeconometric analysis of the retirement decision: Italy (June 1998) Raffaele Miniaci

204. Microeconometric analysis of the retirement decision: Germany (June 1998) Pablo Antolin and Stefano Scarpetta 